\title{
Relationship between climatic indicators and some physiological stages of navel orange trees in West Delta, Egypt
}

\author{
Manal A. Zaky \\ Citrus Res. Dept., Hort. Res. Inst., Agric. Res. Cent., Giza, Egypt.
} Received: 20 Sept. 2020 / Accepted 30 Oct. 2020 / Publication date: 10 Nov. 2020

\begin{abstract}
Field investigations, were performed during two successive growing seasons 2014 and 2015 to assess the suitability of a region for growing navel orange, also to estimate the length of various phenological stages and to predict suitable time for maturity of navel orange by using heat units requirement for this cultivar. The chosen Washington navel orange trees (Citrus sinensis L.) Osbek, budded on sour orange rootstock were ten-year-old, spaced at $5 \times 5$ meters and grown in clay soil, under flooding irrigation system in a private orchard located at Kafr El-Sheikh Governorate, Egypt. The results showed that each phonological stage (root activation, spring flush, flowering and color break) as well as the actual starting dates for each phase recorded more heat units in the second season than the first season, subsequently, the starting dates of each phase was earlier in the second season than first season except in case of color break. With respect to correlation between fibrous root growth and the temperature during both studied seasons, it is obvious that there was strong correlation between either number or weight of roots and soil temperature in both studied seasons. Regarding yield and fruit quality attribute, it is apparent that yield and fruit quality attribute were affected by the changes in the climatic conditions for each season.
\end{abstract}

Keywords: navel orange, phenological stages, heat units requirement

\section{Introduction}

Citrus production occupies the first rank among other fruits production in Egypt, while oranges represent around $65 \%$ of the total Egyptian citrus production. Navel orange is the most cultivated variety in Egypt it occupies about $60 \%$ of total orange area, its acreage reached about 155037 feddans with total production of 1619926 tons per year (Ministry of Agriculture and Land Reclamation/Annual report 2017). Citrus is grown in warm areas with high evaporative demand and where correct irrigation is required to produce maximum yield (Levy and Syvertsen, 1981). Temperature is a very important factor for crop quality and maturation (Davies, 1997 and Goldschmidt, 1997). Flowering is primarily determined by the amount of cool temperatures and /or drought (Valiente and Albrigo, 2004). Citrus cultivars have different temperature requirements for their proper growth and development at various phonological stages. The total accumulation of heat counts during the growing season has a direct influence on the growth and development of the plants (Khan et al., 2016).

Although citrus is adaptable to wide range of climatic conditions but at the same time it is vulnerable to microclimatic condition of certain areas. Among microclimatic conditions temperature seems to be the key element not only affecting the growth but also various other phenological phases of the citrus plants (Khan et al., 2007). Heat units (growth degree days) further affect the quality characteristics of citrus fruits (Khan et al., 2007, Shinohara et al., 2013 and Koshita 2014).

Thus, the goal of this work was to use heat units in citrus to assess the suitability of a region for growing citrus, and to estimate the length of various phenological stages and to predict maturity times for various citrus cultivars.

\section{Materials and Methods}

Field investigations were performed during the two successive growing seasons 2014 and 2015 on 10 years old of Washington navel orange trees (Citrus sinensis L.) Osbek, budded on sour orange rootstock, spaced at $5 \times 5$ meters and grown in clay soil (Table, $1 \& 2$ ), under flooding irrigation system in private orchard located at Kafr El-Sheikh Governorate, Egypt. In this study 25 trees of Washington navel orange cultivar were used. Selected trees were in a good health and condition and nearly uniform 
in both vegetative growth and fruit load. The time of vegetative growth, flowering and petal fall by dates was noted by visual observations on daily basis.

Table 1: Physical and chemical analyses of the experimental soil.

\begin{tabular}{|c|c|c|c|c|c|c|c|c|c|c|c|c|c|c|}
\hline \multirow{2}{*}{ Seasons } & \multirow{2}{*}{$\begin{array}{c}\text { Soil } \\
\text { texture }\end{array}$} & \multirow{2}{*}{ pH } & \multirow{2}{*}{$\begin{array}{c}E C \\
, d S / m\end{array}$} & \multicolumn{4}{|c|}{ Soluble anions, Meq/l } & \multicolumn{4}{|c|}{ Soluble cations, Meq/l } & \multicolumn{3}{|c|}{$\begin{array}{c}\text { Available, } \\
\text { ppm }\end{array}$} \\
\hline & & & & $\mathrm{CO}_{3}$ & $\mathrm{HCO}_{3}$ & Cl & $\mathrm{SO}_{4}$ & $\mathrm{Ca}$ & Mg & $\mathrm{Na}$ & $\mathbf{K}$ & $\mathbf{N}$ & $\mathbf{P}$ & $\mathbf{K}$ \\
\hline 2014 & Clayey & 7.66 & 1.54 & 0.0 & 1.60 & 4.0 & 9.75 & 2.80 & 5.88 & 5.90 & 0.77 & 42 & 61 & 1326 \\
\hline 2015 & Clayey & 8.20 & 1.58 & 0.0 & 1.50 & 3.75 & 10.50 & 2.90 & 6.40 & 5.43 & 1.02 & 47 & 76 & 1400 \\
\hline
\end{tabular}

Table 2: Soil moisture constant for the experiment soil.

\begin{tabular}{ccccc}
\hline Soil depth, cm & Field capacity, \% & Wilting point, $\%$ & Available water, $\%$ & Bulk density, $\mathbf{g} / \mathbf{c m}^{\mathbf{3}}$ \\
\hline $\mathbf{0 - 1 5}$ & 44.52 & 25.3 & 21.7 & 1.16 \\
$\mathbf{1 5 - 3 0}$ & 41.61 & 21.7 & 17.2 & 1.24 \\
$\mathbf{3 0 - 4 5}$ & 38.91 & 21.9 & 16.1 & 1.33 \\
$\mathbf{4 5 - 6 0}$ & 34.96 & 20.9 & 17.7 & 1.37 \\
Average & $\mathbf{4 0 . 0 0}$ & $\mathbf{2 2 . 5}$ & $\mathbf{1 8 . 2}$ & $\mathbf{1 . 2 8}$ \\
\hline
\end{tabular}

Physical and chemical analyses of the experimental soil are shown in Table (1\&2) which was done according to Piper, (1947), Black, (1965) and Jackson, (1967).

The following parameters were measured to evaluate the suitability of west delta region, Kafr EI -Sheikh Governorate for growing navel orange citrus

\section{Meteorological data}

The climatic data (temperature) was obtained from meteorological station at Sakha Agricultural Research Station. The heat units were calculated according to the following formula: Heat units $=(\mathrm{M}-$ 12.8) $\mathrm{N}$

Where $\mathrm{M}$ is mean monthly temperature, 12.8 is the base temperature and $\mathrm{N}$ denotes the number of days of relevant month (Khurshid and Hutton 2005).

\section{Amount of heat unit each phonological stage}

Phonological stage represented in root activation, spring flush, flowering and color break.

\section{Correlation between fibrous roots density average root number and root fresh weight and soil temperature}

Fibrous roots density (average root number and root fresh weight) was determined in soil samples taken monthly from January to October in both seasons at $0-30 \mathrm{~cm}$, depth by soil auger at $100 \mathrm{~cm}$ distance from tree trunk horizontally in four direction. Fibrous roots less than $2 \mathrm{~mm}$ in diameter for each sample were cleaned, counted and their fresh weight was determined as $\mathrm{g} /$ hole which expressed as $1750.80 \mathrm{~cm}^{3}$ or $1.628 \mathrm{~kg}$ soil according to methods described by Cahoon et al. (1959) and Ford, (1962). Soil temperature for each replicate at $30 \mathrm{~cm}$, depth was measured by mercury glass thermometer with 15 day interval from mid- January to mid-October and then monthly average temperature was calculated.

\section{Yield and fruit quality attributes}

At harvest time ( $15^{\text {th }}$ of December in both seasons), yield/tree, fruit weight, height and diameter, rind thickness, juice volume, total soluble solids and acidity were determined.

\section{Statistical analysis:}

The completely randomized design was adopted for this investigation. The obtained data were statically analyzed using the T test according to Steel and Torrie, (1980).

\section{Results and Discussion}

\section{Meteorological data}

Table (3) showed the collected metrological data used to calculate Heat units which is necessary to start activity and vegetative and root growth as well as flowering. 
Rate of plant growth and development is dependent on the temperature surrounding the plant and each species has a specific temperature range represented by a minimum, maximum and optimum. These values were summarized by Hatfield et al. $(2008,2011)$ for a number of different species typical of fruit production.

In agreement with other studies for subtropical areas, Lovatt et al., (1984), Bellows and Morse, (1986) and Ben Mechlia and Carroll, (1989), temperature was the most important environmental factor affecting citrus reproductive response.

Table 3: Some meteorological data for kafr El -Sheikh area during 2014 and 2015 seasons

\begin{tabular}{|c|c|c|c|c|c|c|c|c|c|}
\hline \multirow{2}{*}{ Month } & \multicolumn{3}{|c|}{$\mathrm{T}^{\mathbf{0}} \mathrm{C}$} & \multicolumn{3}{|c|}{ RH \% } & \multirow{2}{*}{$\frac{\text { WS }}{\text { m/sec }}$} & \multirow{2}{*}{$\begin{array}{c}\text { Pan } \\
\text { Evap. } \\
\text { mm/ day }\end{array}$} & \multirow{2}{*}{$\begin{array}{c}\text { Rain } \\
\text { mm }\end{array}$} \\
\hline & Max. & Min. & Mean & Max. & Min. & Mean & & & \\
\hline \multicolumn{10}{|c|}{2014} \\
\hline January & 19.34 & 6.55 & 12.95 & 93.69 & 70.55 & 80.55 & 0.54 & 1.60 & 20.7 \\
\hline February & 20.64 & 8.19 & 14.42 & 91.90 & 67.15 & 79.53 & 0.79 & 2.52 & 16.5 \\
\hline March & 21.14 & 11.71 & 16.33 & 86.10 & 56.80 & 71.45 & 0.96 & 3.14 & 26.2 \\
\hline April & 25.50 & 15.53 & 20.52 & 81.80 & 49.80 & 65.8 & 1.07 & 4.91 & 20.2 \\
\hline May & 30.47 & 19.57 & 25.02 & 77.20 & 48.60 & 62.90 & 1.14 & 5.87 & ----- \\
\hline June & 32.65 & 20.6 & 26.63 & 86.23 & 52.30 & 69.27 & 0.95 & 6.56 & 0.00 \\
\hline July & 33.15 & 23.64 & 28.40 & 83.19 & 55.11 & 69.15 & 1.13 & 7.73 & 0.00 \\
\hline August & 34.10 & 20.80 & 27.95 & 92.40 & 53.50 & 72.95 & 1.15 & 8.14 & 0.00 \\
\hline September & 32.49 & 19.76 & 26.63 & 87.57 & 52.20 & 69.89 & 1.03 & 6.65 & 0.00 \\
\hline October & 29.75 & 17.75 & 24.25 & 80.92 & 53.39 & 67.16 & 0.95 & 4.51 & 0.00 \\
\hline November & 23.30 & 13.79 & 19.05 & 87.80 & 60.50 & 74.15 & 0.78 & 2.77 & 24.6 \\
\hline December & 21.20 & 8.72 & 14.96 & 88.60 & 63.50 & 76.05 & 0.53 & 1.72 & 5.7 \\
\hline Mean & 26.98 & 15.55 & 21.43 & 86.45 & 56.95 & 71.57 & 0.92 & 4.68 & 10.35 \\
\hline \multicolumn{10}{|c|}{2015} \\
\hline January & 19.51 & 8.65 & 13.83 & 88.10 & 61.10 & 74.60 & 0.82 & 2.70 & 52.55 \\
\hline February & 21.79 & 8.46 & 15.12 & 86.80 & 62.70 & 74.75 & 0.84 & 2.90 & 38.8 \\
\hline March & 22.69 & 12.69 & 17.19 & 82.36 & 58.82 & 70.59 & 1.01 & 3.23 & 15.25 \\
\hline April & 27.64 & 13.70 & 20.67 & 78.30 & 48.50 & 63.40 & 1.11 & 6.07 & 35.85 \\
\hline May & 30.19 & 18.79 & 24.49 & 77.3 & 46.1 & 61.7 & 1.33 & 7.15 & 0.00 \\
\hline June & 31.85 & 21.4 & 26.13 & 78.8 & 51.2 & 65.0 & 1.22 & 6.95 & 0.00 \\
\hline July & 34.0 & 22.4 & 27.7 & 85.2 & 54.3 & 69.8 & 1.13 & 6.86 & 0.00 \\
\hline August & 36.1 & 27.0 & 30.1 & 83.8 & 51.7 & 67.8 & 1.06 & 8.15 & 0.00 \\
\hline September & 34.6 & 25.8 & 29.2 & 82.7 & 46.5 & 64.6 & 1.14 & 6.64 & 0.00 \\
\hline October & 29.9 & 21.6 & 25.3 & 80.9 & 54.1 & 67.5 & 1.01 & 4.53 & 65.9 \\
\hline November & 24.50 & 15.79 & 19.05 & 87.80 & 60.50 & 74.15 & 0.78 & 2.77 & 24.6 \\
\hline December & 22.27 & 9.12 & 15.69 & 88.60 & 63.50 & 76.05 & 0.53 & 1.72 & 5.70 \\
\hline Mean & 27.92 & 17.12 & 22.04 & 83.39 & 54.92 & 69.16 & 1.00 & 4.97 & 19.89 \\
\hline
\end{tabular}

$\mathbf{T}=$ Air temperature, $\mathbf{R H}=$ Relative humidity, $\mathbf{W S}=$ Wind speed and, Evap. $=$ Evaporation.

\section{Amount of heat unit each phonological stage}

Data in table (4) showed that the calculated heat units 60, 45, 30 and 15 days before each phonological stage (root activation, spring flush, flowering and color break) as well as the actual starting dates for each proses. Obtained data revealed that each studied physiological phase required more heat units in the second season (2015) than in the first season (2014), subsequently, the starting dates of each phase was earlier in the second season than first season except in case of color break. The calculated heat units $60,45,30$, and 15 days before root activation at $20^{\text {th }}$ of January 2014 were $129.76,52.95$, 25.2 and 2.25 heat unit, respectively, While in the second season at $15^{\text {th }}$ of January 2015 were 182.41 , $88.66,52.17$ and 15.45 heat unit, respectively. In case of spring flush started at $10^{\text {th }}$ of February 2014 in the first season and required 56.59, 28.94, 14.79 and 12.54 heat unit and at $7^{\text {th }}$ of February 2015 in the second season and required $95.69,63.29,39.93$ and 24.48 heat units, respectively.

The flowering started at $15^{\text {th }}$ March 2014 in the first season and $10^{\text {th }}$ of March, while required 100.86, 98.61, 77.25 and 52.95 and 128.16, 112.71, 88.23 and 53.42 heat units in the first and second season, respectively. Color break phase required 906.12, 672.12, 442.62 and 215.37 heat units in the first season and 993.9, 763.2, 503.7 and 246 heat units in the second season and started at $10^{\text {th }}$ of 
September 2014 and $18^{\text {th }}$ of September 2015. Such results indicate that the beginning of each process could be predicted throughout temperature observation and heat unit calculation then determination of proper time of different agricultural applications e.g. irrigation and fertilization which lead to strong start for each growth period then achieving high fruits yield and quality.

Table 4: Amount of heat unit 15, 30, 45 and 60 days before each phonological stage

\begin{tabular}{lccccc}
\hline & Dates & 15 day & 30 day & 45 day & 60 day \\
\hline & \multicolumn{2}{c}{$\mathbf{2 0 1 4}$} & & & \\
Root active & 20 January & 2.25 & 25.2 & 52.95 & 129.76 \\
Spring flush & 2 February & 12.54 & 14.79 & 28.94 & 56.59 \\
Flowering & 15 March & 52.95 & 77.25 & 98.61 & 100.86 \\
Color break & 10 September & 215.37 & 442.62 & 672.12 & 906.12 \\
\hline \multicolumn{5}{c}{$\mathbf{2 0 1 5}$} \\
Root active & 15 January & 15.45 & 52.17 & 88.66 & 182.41 \\
Spring flush & 7 February & 24.48 & 39.93 & 63.29 & 95.69 \\
Flowering & 10 March & 53.43 & 88.23 & 112.71 & 128.16 \\
Color break & 18 September & 246 & 503.7 & 763.2 & 993.9 \\
\hline
\end{tabular}

Responses to temperature differ among citrus species throughout their life cycle and are primarily the phenological responses, i.e., stages of plant development. For each species, a defined range of maximum and minimum temperatures form the boundaries of observable growth.

At $15 / 25$ and $15 / 30^{\circ} \mathrm{C}$ temperatures, flushing occurred both in spring and in summer. Inoue and Harada, (1988) and Inoue, (1989) reported that all satsuma trees grown at ambient temperatures of 15 and $20^{\circ} \mathrm{C}$ had sprouting flushes only in the spring, and the resultant shoots produced some flower buds. Moreover, Moss, (1976) reported that flowering in sweet orange trees occurs whenever shoot growth commences after the trees brought to warm condition.

Under subtropical conditions, citrus flowering occurs primarily during the spring following the inductive winter season (Monselise and Halevy, 1964). During winter, low-temperature conditions cause the inactivity of buds while inducing them to be able to flower (Moss, 1969). As hours of low temperature accumulate, spring bud sprouting shifts from vegetative (with no flowers) to mixed (flowers and leaves) to mostly reproductive (leafless with at least one flower) (Moss, 1969). As for flower intensity, greater accumulation of hours of low temperature increases floral induction, thus increasing number of flowers per tree, number of flowers per node, and sprouting (Poerwanto and Inoue, 1990). The most effective temperatures for induction appear to be in the 10 to $15^{\circ} \mathrm{C}$ range (Valiente and Albrigo, 2004).

Ambient temperature not only has a direct effect on induction and differentiation but also affects flowering date and intensity (Cassin et al., 1969). Flowering (initiation of differentiation to full bloom) in high temperature tropical climates can occur in less than 24 days (Cassin et al., 1969). High temperatures during floral differentiation and expansion shorten development time and advance date of anthesis (Valiente and Albrigo, 2002), but higher temperatures during sprouting also are reported to increase inflorescence leafiness and to inhibit flowering (Moss, 1976) and date of flowering (Valiente and Albrigo, 2002). In addition to high temperatures retard the degradation of chlorophyll and thus the fruit stay green (Reuther, 1973).

\section{Correlation between fibrous roots density average root number and root fresh weight and soil temperature}

Data in table (5) and figure (1\&2) show monthly average fibrous root (less than $2 \mathrm{~mm}$ thick) numbers and weight as well as corresponding soil temperature and correlation between fibrous root growth and the temperature during both studied seasons.

The data clearly indicated that there was strong correlation between either root numbers or weight and soil temperature in both studied seasons. Moreover it is clear that root growth continue during January, February and March, then it almost stopped from March to April, then continued again from April to May and almost stopped from May to June and continue again from June to October, such variance in root growth may be due to changes of physiological processes of the tree for example rapid increase in root growth from January to March to prepare the tree for nutrition consumption during March and April where all the growth go to new leaves and flushes, while the rapid increase of root 
growth during April and May, may be due to nutrition required for trees. During May and June, The slight increase in root growth during July until October may be synchronized with reaching the final growth of the fruits.

Soil temperature affected the fibrous roots density. The amount of growth was positively correlated with soil temperature throughout the year. Moreover, most growth took place during the summer when soil temperatures were above $27^{\circ} \mathrm{C}$. Our observations showed that, although root growth reportedly begins at $13^{\circ} \mathrm{C}$ (Castle, 1978), the level of root growth was relatively minor at soil temperatures below $22^{\circ}$. The latter temperature probably is a meaningful and practical threshold value for root extension growth. Soil temperatures were below $22^{\circ} \mathrm{C}$ in our study during the period from January to April. Since the trees were well watered, soil temperature must have restricted root growth.

Table 5: Correlation between soil temperature and fibrous roots density) average root number and root fresh weight) in 2014 and 2015 seasons

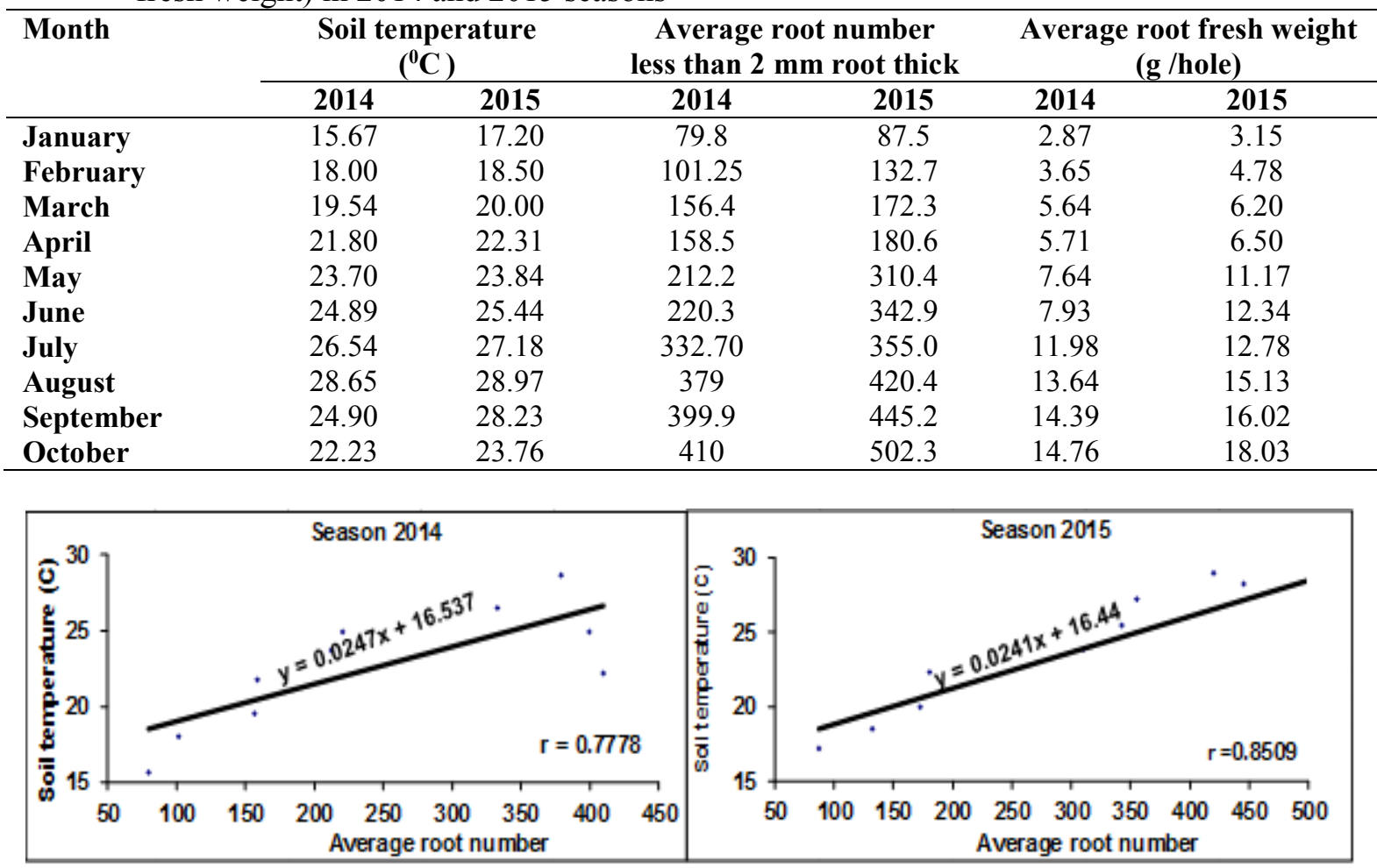

Fig. 1: Relationship between soil temperature $\left({ }^{\circ} \mathrm{C}\right)$ and average root number

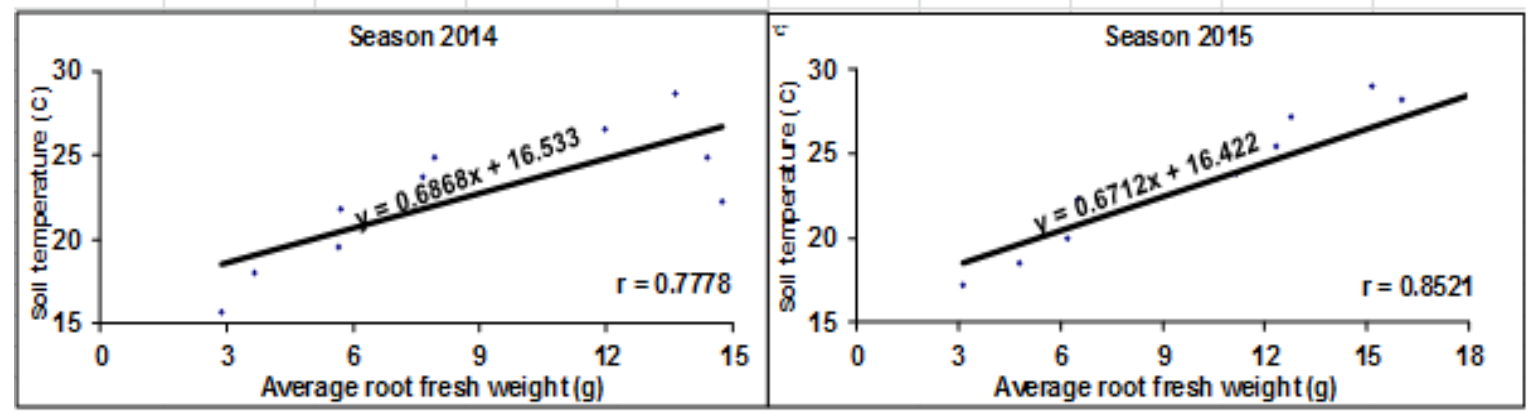

Fig. 2: Relationship between soil temperature $\left({ }^{\circ} \mathrm{C}\right)$ and average root fresh weight $(\mathrm{g})$

\section{Yield and fruit quality attributes}

As shown in table (6), yield and fruit quality attribute were affected by season, which may be related to changes in the climatic conditions.

With regards to yield, significant variations were observed in yield between the first and second seasons. Highest significant value of the yield was gained from the second season $(53.41 \mathrm{~kg} / \mathrm{tree})$ as compared with the first season $(42.91 \mathrm{~kg} / \mathrm{tree})$. 
As for fruit weight, the second season significantly resulted in the highest value in fruit weight, which it was $(269.57 \mathrm{~g})$, whereas the first season had the lowest one $(232.80 \mathrm{~g})$.

With respect to fruit dimensions, it is worth to mention that, no significant differences were observed in fruit length and diameter between seasons under study.

Regarding to rind thickness, insignificant differences were noticed in rind thickness between the two seasons under study.

Table 6: Yield and fruit quality attributes in 2014 and 2015 seasons

\begin{tabular}{ccccccccc}
\hline Season & $\begin{array}{c}\text { Yield/tree } \\
(\mathbf{K g} / \text { tree) }\end{array}$ & $\begin{array}{c}\text { Fruit } \\
\text { weight } \\
(\mathbf{g})\end{array}$ & $\begin{array}{c}\text { Fruit } \\
\text { height } \\
\mathbf{( c m )}\end{array}$ & $\begin{array}{c}\text { Fruit } \\
\text { diameter } \\
\mathbf{( c m )}\end{array}$ & $\begin{array}{c}\text { Rind } \\
\text { thickness } \\
(\mathbf{c m})\end{array}$ & $\begin{array}{c}\text { Juice } \\
\text { volume } \\
(\mathbf{m l})\end{array}$ & $\begin{array}{c}\text { Total } \\
\text { soluble } \\
\text { solids } \\
\mathbf{( \% )}\end{array}$ & $\begin{array}{c}\text { Acidity } \\
\mathbf{\%}\end{array}$ \\
\hline $\mathbf{2 0 1 4}$ & 42.91 & 232.80 & 7.48 & 7.44 & 0.42 & 47.01 & 11.64 & 0.87 \\
$\mathbf{2 0 1 5}$ & 53.41 & 269.57 & 7.96 & 7.43 & 0.46 & 52.56 & 12.02 & 0.86 \\
T. test & S. & S. & N.S. & N.S. & N.S. & S. & S. & N.S. \\
\hline
\end{tabular}

As for juice volume, the second season significantly resulted in the highest value in juice volume, which it was $(52.56 \mathrm{ml})$, whereas the first season had the lowest one $(47.01 \mathrm{ml})$.

With respect to total soluble solids, significant variations were observed in total soluble solids between the first and second seasons. Highest significant percentage of total soluble solids was gained from the second season (12.02\%) as compared with the first season (11.64\%). Regarding to acidity, insignificant differences were noticed in acidity between seasons.

Year to year variation in weather in a given climatic zone can lead to significant yield and fruit quality variation. The suitability of a cultivar to a given climate is mostly related to the species selection in its area of origin and secondarily to special characteristics of some cultivars (Reuther, 1973).

Optimum temperature range in citrus (Citrus sinensis L. Osbeck) is $22-27^{\circ} \mathrm{C}$ and temperatures greater than $30^{\circ} \mathrm{C}$ increased fruit drop (Cole and McCloud, 1985). Very high temperatures during bloom and for the following 2 to 3 months result in excessive fruit drop (Brewer et al., 1977). The progress of the drop waves is also accelerated. If soil moisture is limited, excessive fruit drop occurs until the second drop wave is over (May-June for a spring bloom) (Koo, 1967). After these 2 drop waves are completed, the fruit are very resistant to further drop at least until near harvest (Erickson and Brannaman, 1960).

Fruit size is primarily regulated by number of competing flowers and fruitlets, temperatures, particularly during early development and available soil moisture through most of fruit development. In warmer, more humid climates, fruit size is often acceptable even with a large crop. This is because the higher temperatures from bloom through the first half of fruit development in the tropical climates increase the rate of fruit growth (Reuther and Ríos-Castaño, 1969). This period covers the cell division and major cell enlargement phase of fruit growth (Bain, 1958). In the cooler spring climates of Mediterranean areas, higher temperatures during the first stage of fruit growth can significantly increase fruit size (Marsh, et al., 1999). Ideal temperatures for enhancement of fruit growth rate appear to be in the 20 to $25^{\circ} \mathrm{C}$ range, with both lower and higher temperatures reducing growth rate (Reuther, 1973).

External quality also is affected by tropical climates through larger size, smoother surfaces, but poorer color if loss of green and enhancement of orange pigments is desirable (Reuther and RíosCastaño, 1969). More external waxes are deposited on the surface of oranges grown in a cool, dry climate compared to a warm, humid one (Albrigo, 1973) which results in less weight loss after harvest. Generally, better fresh external quality occurs in cooler fall and winter climates, while better juice quality occurs in intermediate climates that have moderate winters and higher humidity (Reuther, 1973).

General effects of warmer climates on citrus fruit development are as follows: regarding internal quality, high temperatures accelerate fruit growth, the fruit has less time to accumulate soluble solids, and the high respiration rate leads to use of carbohydrates in respiration, which further reduces available sugars for accumulation in the fruit. The high respiration rate may lead to faster turnover of acids (Purvis, 1983) with resulting rapid dissipation of acidity level at higher temperatures (Reuther, 1973).

Faster maturation, due to higher temperatures in the tropics not only leads to lower soluble solids than in intermediate climates and lower acidity than in all cooler climates but also leads to early juice loss (Reuther and Ríos-Castaño, 1969). Citrus fruits start with very high acidity levels that can withstand the degradation of acidity that high temperatures cause (Kurihara, 1969). In this respect, Hutton and 
Landsberg, 2000 found that during fruit development, when the temperatures exceed the optimum range of $13-27^{\circ} \mathrm{C}$ with temperatures over $33^{\circ} \mathrm{C}$ there is a reduction in fruit size, Brix (sugar content) and acid content, and in citrus.

Overall it could be concluded that starting dates of roots activation, spring flush, flowering and color break were affected by dominant temperature, where in worm years each phonological stage started earlier than in cold years, moreover root growth was positively correlated with soil temperature. Yield and fruit quality were certainly affected by prevailing temperature.

\section{References}

Albrigo, L.G., 1973. Some parameters influencing development of surface wax-Citrus fruits. Proc. 1st Int. Soc. Citriculture, 3:107-115.

Bain, J.M., 1958. Morphological, anatomical and physiological changes in the developing fruit of 'Valencia' orange [Citrus sinensis (L.) Osbeck]. Aust. J. Bot., 6(1):1-24.

Bellows, T.S. and J.G. Morse, 1986. Modeling flower development in navel oranges. Sci. Hort., 30:117-126.

Ben Mechlia, B. and J.J. Carroll, 1989. Agroclimatic modeling for the simulation of phenology, yield and quality of crop production II. Citrus model implementation and verification. Intl. J. Biometeorol, 33:52-65.

Black, C.A., 1965. Methods of Soil Analysis. Amer. Soc. Argon. Inc. Madison, Wisconsin, USA. Bull. 3812.

Brewer, R.F., K. Opitz, F. Aljibury and K. Hench, 1977. The effects of cooling by overhead sprinkling on "June Drop" of navel oranges in California. Proc. Int. Soc. Citriculture, 3:1045-1048.

Cahoon, G. A., E.S. Morton, W.W. Jane and M.J. Garber, 1959. Effect of various types of nitrogen fertilization on root density and distribution as related to water infiltration and fruit yield of "Washington Navel" orange in a long term fertilizer experiment. Proc. Amer. Soc. Hort. Sci., 74: 289-299.

Cassin, J., J. Bourdeaut, A. Fougue, V. Furon, J.P. Gaillard, J. Le Bourdelles, G. Montagut and C. Moreuil, 1969. The influence of climate upon blooming of citrus in tropical areas. Proc. First Int. Citrus Symp., 1:315-323.

Castle, W.S., 1978. Citrus root systems: Their structure, function, growth, and relationship to tree performance. Proc. Int. Soc. Citriculture 1:62-69.

Cole, P. and P. McCloud, 1985. Salinity and climatic effects on the yields of citrus. Aust. J. Exp. Agric., 25, 711-717.

Davies, F.S., 1997. An overview of climatic effects on citrus flowering and fruit quality in various parts of the world. In: Stephen HF, Walter JK, editors. Citrus Flowering and Fruiting Short Course. Gainesville. Florida, USA: University of f Florida Press.

Erickson, L.C. and B.L. Brannaman, 1960. Abscission of reproductive structures and leaves of orange trees. J. Amer. Soc. Hort. Sci., 75:222-229.

Ford, H. W., 1962. Thickness of sub soil organic layer in relation to tree size and root distribution of citrus. J. Amer. Soc. Hort. Sci., 82: 177-179.

Goldschmidt, E.E., 1997. Effect of climate on fruit development and maturation. Citrus Flowering \& Fruiting Short Course, April 9-10, Lake Alfred, FL, USA, 93-97.

Hatfield, J.L., K.J. Boote, B.A. Kimball, L.H. Ziska, R.C. Izaurralde, D. Ort, A.M. Thomson and D.W. Wolfe, 2011. Climate impacts on agriculture: implications for crop production. Agron. J., 103, 351-370.

Hatfield, J.L., K.J. Boote, P. Fay, L. Hahn, R.C. Izaurralde, B.A. Kimball, T. Mader, J. Morgan, D. Ort, W. Polley, A. Thomson and D. Wolfe, 2008. Agriculture In: The Effects of Climate Change on Agriculture, Land Resources, Water Resources, and Biodiversity in the United States.

Hutton, R.J. and J.J. Landsberg, 2000.Temperature sums experienced before harvest partially determine the post-maturation juicing quality of oranges grown in the Murrumbidgee Irrigation Areas (MIA) of New South Wales. J. Sci. Food Agric., 80, 275-283.

Inoue, H., 1989. Differentiation and development of flower buds in satsuma mandarins under different temperature conditions. J. Japan. Soc. Hort. Sci., 58: 75-82. 
Inoue, H. and Y. Harada, 1988. Tree growth and nutrient absorption of young satsuma mandarins under different temperature conditions. J. Japan. Soc. Hort. Sci., 57: 1-7.

Jackson, M.L., 1967. Soil chemical analysis. Prentice Hall of India, Pvt. Ltd., New Delhi.115 pp.

Khan, A.R., M.A. Nawaz, M.N. Khan, W. Ahmed, Abdul Rehman, N. Munir and B.A. Saleem, 2016. Heat units requirement of various citrus cultivars grown in Pakistan. J. Environ. Agric., 1(1): 3034.

Khan, A.R., H. Ullah, I.M. Siddique and M. Hafeez, 2007. Ecological nexux for the qualitative production of citrus fruits. Proceedings of the international symposium on prospectus of horticultural industry in Pakistan, Institute of Horticultural Sciences, University of Agriculture, Faisalabad, Pakistan, pp 83-86.

Khurshid, T. and R.J. Hutton, 2005. Heat unit mapping-a decision support system for selection and evaluation of citrus cultivars. Acta Horticulturae, 694: 265-26.

Koo, R.C.J., 1967. Importance of moisture control in citrus groves. Citrus World, September 1967; pp13, 16.

Koshita, Y., 2014. Effect of temperature on fruit color development. In: Yoshinori Kanayama and Alexey Kochetov. Abiotic Stress Biology in Horticultural Plants. Springer, Japan, 44-58.

Kurihara, A., 1969. Fruit growth of Satsuma orange under controlled condition. I. Effects of pre-harvest temperature on fruit growth, color development, and fruit quality in Satsuma orange. Bul. Hort. Res. Sta. Japan Ser. A, No. 8:15-30.

Levy, Y. and J. P. Syvertsen, 1981. Adaptation of citrus trees to climates with different evaporative demands. Proc. Int. Soc. Citriculture 2: 501-503. Tokyo, Japan.

Lovatt, C.J., S.M. Streeter, T.C. Minter, N.V. O’Connell, D.L. Flaherty, M.W. Free-man and P.B. Goodell, 1984. Phenology of flowering in [Citrus sinensis (L.) Osbeck] cv. Washington navel orange. Proc. Intl. Soc. Citricult., 1:186-190.

Marsh, K.B., A.C. Richardson and E.A. McCrae, 1999. Early- and mid-season temperature effects on the growth and composition of satsuma mandarins. J. Hort. Sci. \& Biotech. 74:443-451.

Monselise, S.P. and A.H. Halevy, 1964. Chemical inhibition and promotion of citrus flower bud induction. Proc. Amer. Soc. Hort. Sci. 84:141-146.

Moss, G. I., 1969. Influence of temperature and photoperiod on flower induction and in- florescence development in sweet orange (Citrus sinensis L. Osbeck). J. Hort. Sci. 44: 311-320.

Moss, G.I., 1976. Temperature effects on flower initiation in sweet orange [Citrus sinensis (L.) Osbeck]. Aust. J. Agric. Res., 27: 399-407.

Piper, C.S., 1947. Soil and Plant Analysis. The University of Adelaide Press, Adelaide, Australia, 5974.

Poerwanto, R. and H. Inoue, 1990. Effects of air and soil temperatures on flower development and morphology of satsuma mandarin. J. Hort. Sci., 65:739-745.

Purvis, A.C., 1983. Effects of film thickness and storage temperature on water loss and internal quality of seal-packaged grapefruit. J. Amer. Soc. Hort. Sci., 108:562-566.

Reuther, W., 1973. Climate and citrus behavior, p. 280-337. In: W. Reuther (ed.). The Citrus Industry. Vol. III. Univ. of Calif. Press, Davis.

Reuther, W. and D. Ríos-Castaño, 1969. Comparison of growth, maturation and composition of citrus fruits in subtropical California and tropical Columbia. Proc. First Inter. Citrus Symp., 1; 277-300.

Shinohara, T., M. Usui, Y. Higa, D. Igarashi, T. Inoue, 2013. Effect of accumulated minimum temperature on sugar and organic acid content in passion fruit. Journal of ISSAAS, 19: 1-7.

Steel, R.G.D. and F.H. Torrie, 1980. Principles and Procedures of Statistics. $2^{\text {nd }}$ Edn. McGraw Hill Book Co., New York.

Valiente, J.I. and L.G. Albrigo, 2002. Modeling flowering date of sweet orange [Citrus sinensis (L.) Osbeck] trees in Central Florida based on historical weather records. Proc. Internl. Soc. Citricult. 1:186-190.

Valiente, J.I. and L.G. Albrigo, 2004. Flower bud induction of sweet orange trees [Citrus sinensis (L.) Osbeck]: Effect of low temperatures, crop load, and bud age. J. Amer. Soc. Hort. Sci. 129 (in press). 